PLURAL, Revista do Programa de Pós-Graduação em Sociologia da USP, São Paulo, v. 16, n. 1, pp. 53-80, 2009

\title{
Para além das Múltiplas Modernidades: Eurocentrismo, Modernidade e as Sociedades Periféricas
}

José Henrique Bortoluci*

Resumo: Na literatura recente em Ciências Sociais, o paradigma eurocêntrico da modernidade vem sofrendo ataques de diferentes naturezas. Buscando dialogar com parte dessa literatura crítica, este trabalho (parte de uma pesquisa de mestrado) tem por objetivos: revisar o núcleo articulador da concepçáo eurocêntrica de modernidade e as consequências dessa forma de teorização para a reflexão sobre as sociedades periféricas; apresentar os avanços fornecidos pela perspectiva das "múltiplas modernidades"; e, por fim, apontar os limites dessa perspectiva, a partir de outros discursos teóricos, sobretudo a partir de teorias Pós-Coloniais e da Teoria da Dependência.

Palavras-chave: eurocentrismo; sociedades periféricas; modernidade; múltiplas modernidades.

\section{Beyond Multiple Modernities: Eurocentrism, Modernity and Peripheral Societies}

Abstract: The Eurocentric paradigm of modernity has been suffering different kinds of attacks in the recent literature of Social Sciences. Trying to engage in a dialogue with such literature, this article (part of a M.A. research) has as its mains targets: to revise the fundamentals of the Eurocentric conception of modernity and the consequences of this form of theorizing for the reflection about peripheral societies; to expose the advances provided by the perspective of "Multiple Modernities" and, finally, to point the limits of that perspective and the necessity of engaging with other theoretical discourses, especially with Postcolonial and Dependency Theories.

Keywords: eurocentrism; peripheral societies; modernity; multiple modernities.

* Bacharel em Relaçôes Internacionais (IRI-USP), mestre em História Social (FFLCH-USP) e doutorando em Sociologia (University of Michigan). 


\section{ELEMENTOS DA RAZÃO EUROCÊNTRICA ${ }^{1}$}

O problema da adequação entre categorias ou teorias e a realidade não é novo. Muito pelo contrário, trata-se de uma questáo filosófica fundamental - na verdade, de uma série delas: como atingir o "verdadeiro"? É possível nomear os universais? A realidade é passível de apreensão? Como dar conta da diversidade do dado? Como se relacionam o universal e o particular? Tais questóes filosóficas, que atravessam a história do pensamento humano (não apenas o ocidental), ganham especial importância no interior da discussão moderna sobre a compreensão das sociedades europeias - sociedades em que surge a moderna Sociologia, no interior de um processo de expansão capitalista - e da simultânea compreensão de seus "outros".

A recente literatura pós-colonial, desde o clássico livro Orientalismo (SAID, 2003 [1978]), de Edward Said, vem desenvolvendo uma severa crítica às maneiras pelas quais o discurso da modernidade traz em seu bojo a construção de um oriente que lhe serve como outro.

Para Said, o "orientalismo" é um estilo de pensamento fundamentado em uma distinção epistemológica e ontológica entre o "Ocidente e o Oriente". Essa distinção fundamental seria o ponto de partida para a elaboração de teorias, romances, obras de arte e outras peças culturais sobre o Oriente, seus povos e costumes (SAID, 2003 [1978], p. 2). Porém, o orientalismo não constituiria apenas uma forma de representação: essa duplicação do discurso (Oriente versus Ocidente), própria ao Orientalismo, seria marcada por uma pretensão de estereotipar o outro e de reduzi-lo a determinada essência.

O orientalismo desenvolveu-se como um estilo ocidental de dominar, reestruturar e de exercer autoridade sobre o Oriente (SAID, 2003 [1978], p. 3). Said tenta mostrar que o orientalismo náo é uma fantasia etérea da Europa sobre o Oriente, mas, sim, um grande corpo teórico e prático em que houve, por diversas geraçôes (sobretudo ao longo dos séculos XVIII e XIX, mas com repercussóes que chegam até nossos dias), considerável investimento material. Tendo seus principais elementos desenvolvidos ao longo do enfrentamento europeu contra o Oriente, em sua expansão econômica e militar, o orientalismo seria uma dimensão considerável da cultura política e intelectual moderna (SAID, 2003 [I978], p. I2).

A literatura pós-colonial, à esteira de Said, tenta mostrar que os discursos orientalistas ou eurocêntricos não são dominantes apenas nos primeiros trabalhos da idade contemporânea que trataram de caracterizar o Oriente. A Sociologia, como ciência, origina-se em um ambiente cultural embebido pelo caldo de cultura eurocêntrica. Desde o início, mesmo a proposição de suas questóes fundamentais orientou-se pelo quadro categorial do eurocentrismo. Nesse sentido, os fundamentos da Sociologia moderna foram estabelecidos a partir de estruturas e valores presentes

I Este trabalho é parte da pesquisa de mestrado intitulada "Pensamento Eurocêntrico, Modernidade e Periferia: Reflexôes sobre o Brasil e o Mundo Muçulmano", que vem sendo desenvolvida com financiamento da Fapesp, sob orientação do Professor Doutor Peter R. Demant. Uma versão preliminar deste artigo foi apresentada na mesa "Modernidade, Representação e Nação", no V Simpósio dos Pós-Graduandos em Ciência Política da Universidade de São Paulo, em II de agosto de 2008. 
em sociedades ocidentais, a partir das quais se estabeleceram parâmetros de comparaçắo para o que seriam "sociedades modernas" (Costa, 2006, p. 19; HaLl, 1992, p. 314).

O "Ocidente" passa a ser visto como a cultura padrão, detentora de uma série de características essenciais, em termos das quais as outras sociedades seriam tratadas como deficientes. Dessa maneira, como mostra Turner, uma tabela de atributos positivos e negativos pode ser estabelecida, a partir da qual se podem avaliar os processos históricos de outras sociedades (TURNer, 1994, p. 37).

A modernização, no discurso eurocêntrico, que, em grande medida, informa as teorias sociais clássicas, pode ser confundida com a consumaçáo natural do desdobramento de etapas evolutivas, em sociedades dotadas de certo número de variáveis sociais, e não como um processo contingente, situado no tempo e no espaço e derivado das disputas sociais específicas. A ausência de uma dessas variáveis constitui, dessa maneira, um obstáculo ao desenvolvimento dessas sociedades.

Esse discurso sociológico funda-se em uma duplicação da narrativa, seja ela implícita, seja explícita, a partir da qual se compóe o quadro da "normalidade" ou "completude" tidas como padrão de evolução social, base para a caracterização da "anormalidade" ou "incompletude" das sociedades dotadas de entraves àquele tipo de desenvolvimento.

Como observa Turner com relação à Sociologia orientalista do Islá (mas que certamente poderia ser estendida para o discurso sociológico eurocêntrico, em geral), ela teria se fundado em uma epistemologia particular, predominantemente idealista e essencialista, segundo a qual o fracasso dessas sociedades em se desenvolverem ao longo de trajetos históricos ocidentais até uma sociedade racional, democrática e industrial se explica tendo por referência uma "essência dessas próprias sociedades" (TurNer, I989, p. 88).

Trata-se, em resumo, de uma perspectiva sociológica internalista, de cunho essencialista ${ }^{2}$. Nesse discurso, o "não Ocidente" pode ser definido como um "sistema de ausências", as quais constituiriam, em maior ou menor medida, "obstáculos" ao acesso à modernidade (TuRNER, 1994, p. 39).

Dessa forma, é possível perceber que grande parte das teorias sociológicas clássicas acabou por fornecer dinâmica a uma forma de compreensão do real centrada naquela cisão fundamental entre "moderno ocidental" e "atraso náo ocidental"; entre sociedades dinâmicas e estáticas; impessoais e personalistas; racionais e irracionais - no limite, funcionando como uma atualizaçáo, em um contexto moderno, da cisão grega entre civilização e barbárie3. Em sua estrutura lógica, o pensamento orientalista tem caráter fundamentalmente dicotômico.

2 Não se trata, portanto, de um tipo qualquer de internalismo - como, por exemplo, de uma abordagem marxista tradicional, que restringiria sua análise de uma dinâmica de classes ao interior de um estado ou sociedade. $\mathrm{O}$ essencialismo é fundamental para a caracterização de determinado discurso sociológico como orientalista.

3 A referência a uma proximidade com a dicotomia grega civilização/barbárie não deve ser vista, aqui, como uma tentativa de atestar uma continuidade histórica entre gregos antigos e europeus do século XIX. Como mostram muito bem Dussel (2000) e Shohat e Stam (2006), a partir do argumento já clássico de Martin Bernal (I987), essa pretensa continuidade - o mito da Grécia como lugar "onde tudo começou" (SHOHAT \& STAM, 2006, p. 89) - é parte indispensável ao próprio discurso eurocêntrico, não encontrando uma verdadeira identidade com a realidade histórica. Porém, 
Contudo, o eurocentrismo - termo amplamente encontrado na literatura pós-colonial e em obras que dela se avizinham -, como iremos descrever logo à frente, estende-se bem além do universo delimitado por Said, naquela obra seminal, quando da utilizaçáo do termo "orientalismo". A forma como Said constrói a categoria "orientalismo" deve-se, em grande parte, ao uso particular que esse crítico faz dos trabalhos em que Foucault desenvolve, de forma mais acabada, suas análises de discurso e sua abordagem da constituição da "episteme" ocidental - em especial As Palavras e as Coisas (Foucault, 2007) e A Arqueologia do Saber (1969) -, além de livros em que Foucault descreve a constituiçáo de dispositivos de controle ocidental e a forma como eles servem à constituição da subjetividade moderna, como Vigiar e Punir (1975).

Essa forma de descrever o orientalismo como fornecedor das condiçôes de possibilidade do conhecimento e da ação sobre o Oriente parece amplamente fundamenta na ideia foucaultiana de "episteme"4. Nesse sentido, o orientalismo, apesar de restrito a um determinado setor da experiência ocidental, forneceria, para Said, as condiçóes de possibilidade de todo o conhecimento e de toda a prática direcionada àquela entidade à qual o Ocidente se contrapunha. Ele poderia ser lido como o fundamento de racionalidade de qualquer elaboraçáo intelectual, artística ou política que tematizasse aqueles povos ou regióes.

De forma geral, essa ideia sobre a operação do orientalismo fundamenta-se amplamente em uma concepçáo igualmente foucaultiana sobre as formas de operaçáo do poder: este, disseminado socialmente, constituiria os objetos do conhecimento. Em síntese, Said busca mostrar, em Orientalismo, a constituição de um "Oriente discursivo" como contraponto a um Ocidente em constituição - ou seja, a constituição de um discurso que mediaria ou ordenaria logicamente a relação entre Ocidente e Oriente (Moore-GilberT, I997, p. 38).

Independentemente se "simpáticos" ou não com relação ao Oriente, os discursos ordenados a partir do discurso orientalista seriam dominados por uma vontade de potência do Ocidente

essa proximidade deve ser apontada exatamente por este motivo: o fato de os modernos se identificarem com gregos e romanos (ou com suas instituiçôes - como atestam, por exemplo, a autoidentificação dos revolucionários franceses com os romanos ou a discussão dos últimos dois séculos sobre a democracia) faz com que sejam mobilizadas formas de pensar e ideais de sociedade que pretensamente existiam na "Antiguidade Ocidental", inclusive a dicotomia civilização/ barbárie, que lhe era própria e tão impactante na filosofia, nas artes e na política. A propósito, é notável como essa imagem da Grécia como berço da civilização, em oposição a impérios bárbaros, ainda é mobilizada de forma eficaz - e sem maiores rodeios - pela indústria cultural: o filme "300" (2007, direçâo de Zack Snyder, adaptação para o cinema dos quadrinhos de Frank Miller) talvez seja a mais recente demonstração em massa de como os discursos eurocêntricos constituem-se como parte central da imaginação social do Ocidente e de como eles se prestam a reforçar determinada narrativa geral sobre a história da humanidade - narrativa que vem de mãos dadas com concepçôes políticas bastante inequívocas sobre como tratar esse outro, que há tantos séculos atormentaria nossa vivência "moderna", "ocidental", "aos moldes gregos", como se queira.

4 Esse conceito, em Foucault, é fundamental para suas reflexôes sobre as possibilidades do conhecimento e sobre a constituiçáo das disciplinas ocidentais. A episteme é a concatenaçáo de práticas discursivas de uma determinada época, dotada de regras e condiçóes a partir das quais o próprio conhecimento se torna possível. Foucault descreve a episteme como o espaço "(...) onde os conhecimentos, encarados fora de qualquer critério referente a seu valor racional ou a suas formas objetivas, enraízam sua positividade e manifestam assim uma história que não é a de sua perfeição crescente, mas, antes, a de suas condiçóes de possibilidade" (Foucault, 2007 [1966], p. I8). 
sobre o Oriente - este seria descrito como essencialmente sem voz, sensual, feminino, despótico, irracional e atrasado, sendo o Ocidente seu negativo.

Não é grande surpresa apontar que Orientalismo recebeu críticas muito próximas àquelas feitas ao estruturalismo e ao pós-estruturalismo em geral. $\mathrm{O}$ alvo fundamental é a própria categoria de "orientalismo", que, em muitos momentos, não deixa margem para a diferença em seu interior; essa categoria, em outros termos, traz dificuldades para a análise de obras individuais e contextos específicos, assim como impóe barreiras a uma consideração das disputas constantes (políticas e intelectuais) a respeito das possibilidades de representação do náo ocidental. Em síntese, o maior risco das investidas de Said é a descriçáo do orientalismo como um mal congênito do Ocidente: o orientalismo pode ser lido como uma espécie de ontologização da incompreensão ocidental sobre o oriental.

Essas críticas refletem-se em trabalhos pós-coloniais posteriores, inclusive em obras de autoria do próprio Said. Em Cultura e Imperialismo (SAID, I995), Said afasta-se da influência determinante de Foucault - apesar de não abandoná-lo, por certo - e aproxima-se de teóricos marxistas (sobretudo Gramsci e Raymond Williams) e de "vozes insurgentes" antieurocêntricas - em particular, de pensadores "descoloniais" e periféricos, como C. L. R. James e Frantz Fanon.

Esse desenvolvimento ulterior da crítica saidiana abre um caminho para uma leitura mais flexível e, decerto, mais proveitosa dos problemas tratados em Orientalismo. Distanciado daquele primeiro estruturalismo dramático, Said continua a fornecer importantes consideraçôes sobre as temáticas e categorias que permearam as formas ocidentais de fazer sentido sobre as sociedades orientais. Para isso, sai de cena o "orientalismo" e passa-se a trabalhar a partir de uma ideia de "estruturas de atitudes e referências" (com base no trabalho do crítico marxista Raymond Williams) nas formas de intercâmbio cultural entre Ocidente e Oriente; uma estrutura apropriada de formas diversas por atores em contextos específicoss.

Essa nova forma de avançar uma crítica ao pensamento eurocêntrico aproxima o trabalho de Said daquele de diversos outros pensadores sociais, políticos e teóricos pós-coloniais e subalternos contemporâneos que vêm se debruçando sobre a construção de discursos teóricos e políticos sobre as sociedades náo ocidentais, trabalhos estes produzidos nessas sociedades, seja em um contexto imperial, seja em um contexto de grande assimetria de poder.

Nesse sentido, sem que se lance mão de uma espécie de enteléquia teórica de validade universal, pode-se pensar nas formas como uma "consciência europeia da modernidade" foi se constituindo ao longo dos últimos séculos e, simultaneamente, produzindo uma imagem do náo idêntico (o náo europeu, o colonial, o oriental...) que se manteve atrelada a uma imagem de si, funcionando como seu princípio de legitimidade e garantia de superioridade.

5 Nos termos de Said: “(...) quero mostrar que a 'estrutura de atitudes e referências' prevalece e exerce influência de todas as maneiras, em todas as formas e lugares, mesmo bem antes da chamada era do Império; longe de ser autônoma ou transcendente, ela está próxima do mundo histórico; longe de ser fixa e pura, ela é híbrida, partilhando da superioridade racial bem como da genialidade artística, da autoridade política bem como da técnica, de procedimentos simplistas e redutores bem como de métodos complexos" (SAID, I995, pp. I55-I56). 
O eurocentrismo pode ser visto, dessa maneira, como o imaginário dominante do sistema do mundo moderno (Mignolo, 2003, p. 49; Wallerstein, 2007) - um conjunto de categorias e imagens de mundo adaptável às alteraçôes na organização do poder global, mas sempre emitido a partir de um ponto de vista do centro europeu/ocidental desse sistema.

De forma esquemática, Turner busca descrever os principais componentes do discurso "orientalista" (Turner, 1994, pp. 96-99). Creio que, a partir de nossas consideraçôes, é possível nos orientarmos por esse raciocínio de Turner e tentar expandi-lo, buscando descrever os principais elementos do quadro categorial de uma Sociologia eurocêntrica - ou, em outros termos, de um setor sociológico de uma estrutura de atitudes e referências eurocêntricas.

Primeiramente, o eurocentrismo pode ser visto como uma teoria do poder despótico. O segundo componente é a incorporaçáo, nesse discurso, de uma teoria sobre a transformação social (ou, na verdade, de uma teoria sobre a ausência de transformaçáo). Em terceiro lugar, o discurso orientalista apresenta uma teoria da sexualidade oriental ou não ocidental, em contraponto a um pretenso ascetismo ocidental. Por último, esse discurso incorpora uma teoria da disciplina e da racionalidade, pretensos traços ocidentais ausentes em sociedades não ocidentais.

A esses elementos deve-se adicionar um quinto: o internalismo essencialista - a ideia de que há uma "essência cultural" que determina o desenrolar da história de certa coletividade humana, hipótese que afastaria a necessidade de se avaliar (ou de se dar centralidade analítica) às disputas internas entre grupos e indivíduos pertencentes a essas coletividades ou às relaçóes entre eles e membros de outras coletividades.

Relembro, por fim, que, em termos de estrutura lógica do discurso, o eurocentrismo pode lançar mão do dualismo e de alguma forma de evolucionismo histórico ${ }^{6}$. A articulaçáo entre dualismo e evolucionismo é a forma lógica de organização de discursos históricos que - lançando máo de análises sobre estruturas de poder, racionalidades e formas de vida ou de padróes de organização social que perduram no tempo, em sociedades tipicamente não entendidas como ocidentais - se organizam em torno de uma dicotomia básica entre completude (a experiência social moderna/ocidental tida como típica) e incompletude (sociedades "atrasadas", que poderão "chegar lá"), em formas de narrativa em que a História pode ser descrita como uma espécie de "sala de espera" (ChaKrabarty, 2000, p. 8).

O problema fundamental desse setor sociológico da estrutura de referências eurocêntricas refere-se, em síntese, às formas de pensar que orientam a narrativa da modernidade (e das possibilidades da "transição" a ela), a partir das quais cada uma das histórias nacionais é investigada.

O indiano Dipesh Chakrabarty aponta uma tendência de que todas as histórias de naçóes periféricas particulares se tornam variaçôes de uma narrativa mestra - a própria narrativa da

6 É preciso advertir, porém, que os autores que trabalham a partir de uma perspectiva eurocêntrica ou que são, de alguma forma, influenciados por ela năo se utilizam de todos esses elementos, necessariamente. Em geral, esses cinco elementos são utilizados seletivamente, conforme a sociedade analisada, a postura intelectual ou política do autor ou a questão a que se quer dar destaque. 
história da Europa -, que alocaria cada uma dessas histórias nacionais em uma posiçấo de subalternidade (CHAKRABARTY, 2000, p. 27).

Nesse sentido, apenas a história da Europa, aquela narrativa mestra a que se refere Chakrabarty, seria passível de formulação teórica: "only 'Europe', the argument would appear to be, is theoretically (that is, at the level of the fundamental categories that shape historical thinking) knowable; all other histories are matters of empirical research that fleshes out a theoretical skeleton that is substantially 'Europe'" (CHAKRABARTY, 2000, p. 29; destaque no original).

Essa forma de fazer sentido da história das sociedades não ocidentais é penetrante até mesmo nos esforços mais recentes de compreensão científica da realidade dessas sociedades. Não se trata apenas de artigos de um antiquário científico - obras fundadoras de nossas ciências sociais, resquícios de formulaçôes racistas do século XIX ou aplicaçôes imediatas da teoria da modernizaçáo à dinâmica dessas sociedades. Há vários indícios de que as antinomias do pensamento eurocêntrico organizam argumentos clássicos e algumas das mais importantes obras recentes que tratam, por exemplo, do Brasil e das sociedades árabes e muçulmanas, além de serem altamente impactantes para a dinâmica política interna e para as relaçôes internacionais dessas sociedades.

Essa hipótese nos leva a crer que a crítica ao eurocentrismo deve adquirir uma função crítica permanente; ela deve passar a fazer parte de nossos aparatos teóricos (e políticos, dada a importância dos temas tratados) cotidianos e assumir um papel de ponto de partida para uma análise da dinâmica entre pensamento e política e, fundamentalmente, para o estudo das sociedades periféricas. Estudo esse entendido como um verdadeiro esforço intelectual de compreensáo imbuído de um momento ético de transformação do real. A formulação de uma teoria crítica da modernidade periférica deve passar, portanto, por um momento de desconstruçáo das antinomias do pensamento eurocêntrico.

\section{ALGUMAS CONSIDERAÇÕES SOBRE ORIGENS E COMPONENTES DO DISCURSO EUROCÊNTRICO}

Como já expresso anteriormente, o eurocentrismo, em suas várias dimensôes, forma uma das bases da própria experiência ocidental da modernidade. Segundo Lander, o eurocentrismo pode ser apresentado, sinteticamente, como a naturalizaçáo da sociedade liberal europeia como a única possível ou desejável (LANDER, 2000, p. I2). Essa naturalização seria, em seus aspectos epistemológicos, uma das muitas consequências de uma separaçáo, fundadora do pensamento político ocidental moderno, entre homem (razão) e mundo. Uma das decorrências dessa cisão é uma pretensa busca por conhecimento descorporeizado e descontextualizado, objetivo e universal, busca essa atrelada a uma noçáo de progresso, desenvolvida em um contexto de assimetria de poder global.

Para a consciência europeia da modernidade, essas sucessivas cisões da realidade articulamse com aquelas que servem de fundamento ao contraste essencial que se estabelece a partir da conformação colonial e neocolonial do mundo, entre a Europa e os "outros". Dessa articulação 
surge um campo teórico, imagético e ideológico que apregoa o suposto caráter universal da experiência europeia e que possibilita uma leitura da totalidade da experiência humana a partir dessa particularidade (LANDER, 2000, pp. 16-17).

Como aponta Abdel-Malek (1975, p. 47), há um caráter setorial no dado que informa a Sociologia. Essa setorialidade do dado, que naturaliza uma experiência histórica, é a base para uma história excludente ou uma história das incompletudes e dos bloqueios.

Tentando captar as múltiplas dimensões desse discurso eurocêntrico, Coronil o define (muito peculiarmente denominando-o de "ocidentalismo") da seguinte maneira:

...conjunto de prácticas representacionales que participan en la producción de concepciones del mundo que I) dividen los componentes del mundo en unidades aisladas; 2) desagregan sus historias de relaciones; 3) convierten la diferencia en jerarquia; 4) naturalizan esas representaciones; y 5) intervienen, aunque sea de forma inconsciente, en la reproducción de las actuales relaciones asimétricas de poder (CORONIL, 2000, pp. 89-90).

A construçáo sociológica interior ao discurso eurocêntrico, a que vimos nos referindo, funciona como uma espécie de "dispositivo de conhecimento universal" (LANDER, 2000, p. 23) que, ao hierarquizar as diversas experiências humanas e colocá-las ao longo de uma reta que as distancia ou aproxima da "experiência da modernidade", permite a descrição das outras formas de vida, em sentido negativo, ou seja, como formas incompletas - e não como outras formas particulares de completude.

Em algumas variaçóes do discurso eurocêntrico vigora uma forma de compreensão do progresso em níveis mundiais, que Blaut chama de "difusionismo eurocêntrico". Segundo essa visão, o progresso seria permanente e natural na Europa e não no resto (o que é geral para todo o discurso eurocêntrico), e o progresso nos outros locais seria principalmente resultado da difusáo de ideias inovadoras e de produtos europeus (BLAUT, 2000, p. II).

Blaut tenta esclarecer que esse modelo de evoluçâo histórica global ganhou realidade e poder com o colonialismo europeu.

Esse entrelaçamento entre discursos eurocêntricos e a lógica assimétrica de poder global é um dado que não se pode perder de vista. Essa observação é especialmente importante e nos obriga a ler com atenção diversas críticas feitas a autores pós-coloniais e, sobretudo, a Edward Said, no que se refere às bases de seu aparato crítico ao discurso eurocêntrico.

Em diversos momentos da primeira crítica saidiana, o orientalismo parece ganhar ares de entidade autônoma de dominação, uma espécie de discurso que se autorreproduz, inventando outro para a autoinvençáo e a dominação europeias. O que parece escapar a diversos críticos pós-coloniais é a centralidade da "colonialidade do poder" própria à modernidade (QuiJANO, 2000) ou ao capitalismo, instalando-se globalmente.

Essa expansăo do capitalismo carrega formas de conhecimento dominadoras, que se instalam na periferia e são aí, em inúmeros casos, reproduzidas - e, como aponta Coronil na 
citação anterior, intervêm conscientemente ou inconscientemente na reprodução das relaçóes assimétricas de poder dadas.

Ahmad nos ajuda a compreender esse processo:

O que estou sugerindo é que tem havido historicamente todos os tipos de processos - ligados a gênero e classe, etnicidade e religiáo, xenofobia e intolerância - que infelizmente têm estado em ação em todas as sociedades humanas, tanto europeias quanto não europeias. O que deu especial força às formas europeias desses preconceitos, na história, com consequências devastadoras para as vidas de incontáveis milhóes e expressos ideologicamente em racismos eurocêntricos plenamente desenvolvidos, não foi um processo trans-histórico de obsessão e falsidades ontológicas - uma concentração de singular força nos domínios do discurso - mas, muito especificamente, o poder do capitalismo colonial, que fez surgir outros tipos de poderes (AHMAD, 2002, p. I33).

Assim, não nos deve escapar que o que faz do eurocentrismo algo diferente dos outros etnocentrismos é exatamente o capitalismo e seu caráter mundial e assimétrico (conforme DirLIK, 2003, p. 307). A ideia de um discurso eurocêntrico (ou qualquer outra forma de descrever esse conjunto de dispositivos representacionais) só ganha sentido real quando se considera, nos termos de Quijano (Dirlik, 2003, p. 222), mais uma vez, a colonialidade do poder própria do sistema-mundo capitalista moderno.

É apenas tendo essa caracterização em mente que se pode avaliar o papel das ciências sociais em todo o mundo periférico, no qual elas adquiriram, com enorme frequência, o papel de formas privilegiadas $^{7}$ do estabelecimento de afirmaçôes sobre a ausência ou os bloqueios à modernidade, em vez de se constituírem como geradoras de conhecimentos dessas sociedades a partir de suas especificidades históricas, sociais e culturais. Para o caso da América Latina (mas apresentando um quadro de fácil generalização), Lander afirma:

En América Latina, las ciencias sociales, en la medida en que han apelado a esta objetividad universal, han contribuido a la búsqueda, asumida por las elites latinoamericanas a lo largo de toda la historia de este continente, de la "superación" de los rasgos tradicionales y premodernos que han obstaculizado el progreso, y la transformación de estas sociedades a imagen y semejanza de las sociedades liberales-industriales [...] A partir de caracterizar las expresiones culturales "tradicionales" o "no-modernas", como en processo de transición hacia la modernidad, se les niega toda la posibilidad de lógicas culturales o cosmovisiones propias.

7 Certamente, essa não é uma descrição exaustiva sobre as ciências sociais nos países que não fazem parte do centro, da mesma forma como nem todo o pensamento produzido deve ser descartado como eurocêntrico, orientalista, ideológico ou qualquer coisa do tipo. Pelo contrário: uma vasta produção teórica, em larga medida elaborada em contextos periféricos e considerando suas particularidades, vem tentando superar as antinomias do discurso eurocêntrico. 
Al colocarlas como expresión del pasado se niega la posibilidad de su contemporaneidad (LANDER, 2000, p. 26) .

Até agora, o que se tentou fazer foi identificar as maneiras de como o discurso eurocêntrico impacta na compreensão sobre o desenvolvimento histórico e as dinâmicas sociais em sociedades periféricas. O que se espera que reste de saldo dessa breve reflexão é a inadequação dessas categorias e narrativas na compreensão daquilo a que ela se propôe - as sociedades analisadas, a partir desses discursos sociológicos eurocêntricos, não são entendidas em sua formação específica, em um quadro que as situe em uma dinâmica social que vai além de suas fronteiras. O que resta é uma descriçẫo de incompletude frente a um modelo que lhes é inatingível.

Mas, invertendo tal raciocínio, seria possível pensar o Brasil, as sociedades árabes e muçulmanas e outras sociedades periféricas a partir da ideia de completude? O que se haveria "completado" nessas sociedades, ou, dito de outra forma, como o presente delas pode ser entendido em sua dignidade histórica, sem que ele seja descrito como dado inacabado? Essas questóes são uma versão específica daquelas com que iniciamos esta segunda parte. Nosso problema é: que aparatos categoriais e procedimentos metodológicos nos permitem fazer "afirmaçôes verdadeiras" sobre essas sociedades periféricas e, ao mesmo tempo, procedermos a uma crítica da modernidade a partir dessa posição? O momento da crítica deve abrir espaço a um esforço construtivo, que é no que tentarei focar-me, por meio da busca e análise de algumas referências teóricas que buscaram realizar projetos diversos de "descolonizaçáo" teórica.

Portanto, sem buscar desenvolver qualquer abordagem nova (o que seria inapropriado e irrealizável para uma pesquisa como esta), o objetivo das reflexôes propostas é apontar os caminhos já trilhados por diferentes literaturas e tentar articulá-los à luz de nossos problemas de pesquisa e de nossas hipóteses. A questáo fundamental que nos guia é a maneira como os quadros categoriais consideram as especificidades do processo de modernizaçáo na periferia e as especificidades da modernidade em sociedades periféricas, situando essas sociedades em uma dinâmica de modernidade-capitalista global e atendo-se às dinâmicas internas entre grupos sociais.

Esse esforço exploratório parte de uma dissociação entre a modernidade e o Ocidente. Em seguida, analiso a recente literatura sobre as múltiplas modernidades, buscando identificar seus avanços e apontar suas fragilidades. Por fim, tento esboçar brevemente um programa de pesquisa voltado à reflexáo sobre um empreendimento teórico que busque superar as fragilidades.

8 Essa caracterização de Lander sobre a busca da superação dos bloqueios ao progresso e da instauração de uma ordem social liberal assemelha-se à caracterizaçáo que Werneck Vianna faz do "americanismo" na história do pensamento social brasileiro (Werneck Vianna, 1997). Para o caso brasileiro (e, se seguimos as pistas de Lander, o latino-americano), o americanismo parece constituir a versão mais vigorosa e corriqueira de discurso eurocêntrico. 


\section{MODERNIDADE E OCIDENTE}

O discurso sociológico eurocêntrico, descrito até o momento, parte de uma premissa sobre as relaçôes entre a modernidade, com suas instituiçôes e seus modos de vida característicos, e o Ocidente. Aquela teria sido gerada no interior deste; a modernidade seria um "fenômeno ocidental", de forma que ambos, tomados como agregados culturais, poderiam ser vistos como sinônimos.

O termo "ocidental", nesse sentido, seria, no mais das vezes, equivalente a europeu, quando se refere a fenômenos até o século XIX; a partir de então, a América anglo-saxá também passaria a ser entendida como parte desse conglomerado civilizacional. É grande, por certo, a dificuldade e imprecisáo em se definir qualquer um desses termos, uma vez que eles parecem congenitamente entrelaçados e são utilizados, em geral, de maneira intercambiável, na mais vasta gama de discursos sociológicos, políticos ou do senso comum.

Grande parte do pensamento atual que trata de sociedades periféricas e que, de alguma forma, desenvolve algum tipo de discurso eurocêntrico sofreu uma influência indireta daquele corpo teórico original, principalmente por meio do pensamento sociológico moderno. Referimo-nos, sobretudo, às sociologias de Marx e Weber. Os dois autores, centrados em questóes sobre o desenvolvimento do capitalismo e a racionalizaçáo, processados no Ocidente, utilizam, de formas distintas (e variáveis, ao longo de suas obras), uma série de categorias e abordagens originadas em uma distinção fundamental entre Ocidente e não Ocidente.

Apesar da complexidade de suas obras, é inegável que, em diversos momentos, os autores lançam máo de abordagens internalistas e fornecem contribuiçóes para a reafirmação dos elementos marcantes da estrutura de atitudes e referências eurocêntricas (HALL, I992; TuRNER, 1989; 1994).

No interior de nossas preocupaçôes, é preciso destacar, inicialmente, o uso da ideia de obstáculo por ambos os autores. Em Marx, essa ideia é sintetizada no conceito de "Modo Asiático de Produção", sendo este, como mostra Anderson, uma variação do conceito orientalista clássico de "Despotismo Oriental" (Anderson, 1985, pp. 46I-494)

9 Não se trata aqui, evidentemente, de denunciar o uso desses clássicos para a reflexão sobre essas sociedades periféricas, o que seria uma proposta completamente descabida. Contudo, é igualmente incorreto não nos atermos a como grande parte do pensamento social contemporâneo dessas sociedades, que busca fazer sentido, reproduz aspectos problemáticos da obra desses autores, em especial, suas abordagens sobre as sociedades não ocidentais.

Io Nimtz (2002) e Jani (2002) desenvolvem interessantes críticas ao tratamento de Marx, como um autor eurocêntrico, centrando-se, sobretudo, na dialética entre teoria e prática, na produção intelectual e na atuaçáo política desse autor. Contudo, nenhum deles debruça-se sobre a construçáo do conceito de Modo Asiático de Produção na obra de Marx. De qualquer forma, algumas das observaçôes e citaçôes de Marx nos auxiliam a desenvolver leituras de sua obra que não sejam esquemáticas e etapistas. A seguinte afirmaçáo de Marx, em uma carta a um grupo de revolucionários russos, de I877, deverá ser de grande valia para nossas análises posteriores sobre os problemas de um discurso sociológico eurocêntrico; Marx adverte contra a transformação de seu "historical sketch of the genesis of capitalism in Western Europe into a historical-philosophical theory of general development, imposed by fate on all peoples, whatever the historical circumstances in which they are placed" (MARX, 2000 apud; NIMTZ, 2002, p. 75). José Aricó, marxista argentino, aponta que o pensamento de Marx sofre uma espécie de "virada antieurocêntrica" na fase final de sua vida, a partir 
Em Weber, como se apreende a partir da análise de Schluchter (1996, p. I20), a ideia de obstáculo encontra-se principalmente nos pontos que balizam sua análise comparativa sobre as diferentes éticas econômicas: tipo de estado, leis, ciência e conduta de vida, podendo cada um desses elementos prover resistências ou não à ascensão do capitalismo racional - caso sirvam ou não à reafirmação da estereotipificação, essa inibidora do "fluxo racional da vida cotidiana" (Pierucci, 2003, p. 13i). Além disso, em ambos os clássicos há uma dicotomia de fundo entre o caráter dinâmico das sociedades ocidentais, em contraposição ao caráter estático das sociedades orientais (TuRNER, I989, capítulo I).

Esta famosa citação de Weber, de sua introdução aos Ensaios Reunidos de Sociologia da Religião, é um caso clássico do mecanismo de identificação entre "modernidade" e "Ocidente":

[One who is] a product of modern European civilization, studying any problem of universal history, is bound to ask himself to what combination of circumstances the fact should be attributed that in Western civilization, and in Western civilization only, cultural phenomena have appeared which (as we like to think) lie in a line of development having universal significance and value. Only in the West does science exist at a stage of development having universal significance and value. Only in the West does science exist at a stage of development which we recognize today as valid. [The full] development of a systematic theology must be credited to Christianity [...] since there were only fragments and in a few Indian sects [...] Indian geometry had no rational proof; that was another product of the Greek intellect, also the creator of mechanics and physics [...] The highly developed historical scholarship of China did not have the method of Thucydides. [All] Indian political thought is lacking in [...] rational concepts. [Rational] harmonious music, both counterpoint and harmony [...] our orchestra [...] our sonatas, symphonies, operas [...] all these these things are known only in the Occident [...] In architecture [...] the rational use of the Ghotic vault [...] does not occur elsewhere. [The] Orient lacked [...] that type of classic rationalization of all art [...] which the Renaissance created for us. There was printing in China. But a printed literature [...] and, above all, the Press and periodicals, have appeared only in the Occident. [The] feudal state [...] has only been known to our culture [...] In fact the State itself [...] is known [in the full sense] only in the Occident. And the same is true of the most fateful force in our modern life, capitalism. [The] concept of the citizen has not existed outside the Occident (Weber apud BlaUt, 2000, p. 25).

do estudo de sociedades periféricas (em especial a Rússia), quando passa a incorporar a ideia de que “(...) o modo capitalista de produção está condicionado por modos de produção que não se encontram no mesmo estágio alcançado pelo desenvolvimento do primeiro" (ArIcó, I982, p. 58). A partir daí, Marx passa a trabalhar com um conceito de capitalismo mundial cujos desdobramentos aproximam-se daquilo que Trotski teorizou, posteriormente, a partir da ideia de "desenvolvimento desigual e combinado". 
A extensão da citação se justifica dado o enorme número de exemplos de raciocínio eurocêntrico fornecidos por Weber. O que há de especial interesse é a forma como o autor arrola, ao longo de sua argumentação, uma série de instituiçôes e formas de conduta próprios à ideia de modernidade (inclusive a dele próprio), identificado-as como intrínsecas ao Ocidente. Ciência, Estado e racionalidade (com suas aplicaçóes nas artes, na arquitetura, na teologia) sáo instituiçôes que definem tanto o Ocidente (ou a civilização europeia moderna, como expressa Weber) quanto a própria modernidade. Essa identidade dos termos faz com que Weber incorra em certo raciocínio circular, sobretudo porque seu critério de racionalidade, espécie de fita métrica por ele utilizada para avaliar condutas de vida e bens culturais com relação àqueles do Ocidente, é ele próprio ocidental.

Contudo, apontaria ainda outra questão fundamental, anterior a essas: a forma como Weber estabelece o enquadramento de questóes que ele se propóe a resolver é que o encaminha por uma via eurocêntrica. A questáo sobre os motivos do surgimento da modernidade "no Ocidente" é típica de um raciocínio internalista, com maior ou menor proximidade do essencialismo. Esse tipo de colocação do problema - colocação que é uma parte fundamental do raciocínio científico e altamente dependente dos valores do próprio cientista, como, aliás, o próprio Weber afirmaria (conforme Löwy, 2007) - fundamenta-se em uma visão da história mundial que dissocia cada uma das sociedades ou civilizaçóes, tratando-as como unidades ilhadas. Assim, antes de nos atermos às possíveis respostas fornecidas por Weber, é de fundamental importância a observação da ideia de história mundial que orienta sua colocaçáo de perguntas.

Como aponta Demant, o conceito de "Europa", da forma como se desenvolveu ao longo da Idade Moderna, é um produto da era do Renascimento e da Reforma. Até entâo, o continente teria passado por uma complexa história de unificação e fragmentação que data da Antiguidade, sem que se gerasse uma base comum de identificação cultural. É na época moderna que a "Europa" evolui de conceito geográfico para civilizacional. Ao longo do século XVI, esse conceito vai se constituindo em torno de três critérios: I) não islä (exclusão da parte do continente dominado por povos muçulmanos); 2) cristão ocidental (exclusão da parte dominada pelos ortodoxos, na Europa Oriental); e 3) enraizamento na Antiguidade Clássica Pagã (identificaçáo com os padrôes políticos e estéticos atribuídos aos gregos e romanos pré-cristãos) (DEMANT, 2007, p. 27).

Demant - partindo da análise de Samuel Huntington, mas a expandindo - procura articular quais seriam as características comuns da civilização ocidental. A lista é longa:

(I) individualismo e seu corolário [...]; (2) racionalismo [...]; (3) domínio da lei [...]; (4) cristandade; (5) partilha do poder através de instituiçóes representativas [...]; (6) separação entre Estado e religião, que abriu o caminho para a tolerância religiosa e eventualmente o secularismo e a neutralidade religiosa do espaço público; (7) pluralismo, a legítima coexistência pacífica de grupos e projetos mutuamente incompatíveis dentro de uma sociedade [...]; (8) feudalismo e capitalismo; (9) a crença no progresso e na perfectibilidade e emancipação [...]; (Io) a ciência como método universal para a aquisição de 
conhecimento objetivo [...]; (II) direitos civis e humanos universais [...]; (I2) a soberania do povo, encarnada na cidadania e democracia participativa [...]; (I3) autodeterminação da naçấo e nacionalismo, encarnados no Estado-Nação independente [...]; e finalmente (I4) a ideia da irmandade dos homens, da responsabilidade mútua, justiça social e paz [...]; A fim de que a lista acima não soe demasiadamente idealista, adicionemos que (I5) escravidão, (I6) racismo e (I7) guerra, militarismo e expansionismo têm diversas vezes sido propostos como marcas do Ocidente! (Demant, 2007, pp. 4I-42).

E com relação ao conceito de modernidade? De forma resumida, é possível perceber, na maioria das teorias sociológicas clássicas e contemporâneas que lhes dão continuidade, a identificação da modernidade com um princípio que se materializa em instituiçóes e modos de vida. Habermas (2002, p. 28), ao analisar o núcleo fundamental dos discursos filosóficos da modernidade, busca decantar o princípio da subjetividade como aquele que articularia suas várias manifestaçóes. Esse princípio, em circulação ao menos desde Descartes, seria apreensível por meio do individualismo, do direito à crítica, da autonomia da ação e da filosofia idealista que iriam se constituir no Ocidente.

Para Habermas, os acontecimentos-chave para a instauração desse princípio e, portanto, da própria modernidade teriam sido a Reforma Protestante, o Iluminismo e a Revolução Francesa. A subjetividade, articuladora global de uma "forma de ser" moderna, determinaria as várias manifestaçóes da cultura moderna, como a ciência, a moral, a arte (sobretudo o romantismo), a religiáo e o Estado ${ }^{\text {II }}$.

Essa justaposição entre as definiçóes de modernidade e civilização ocidental (como entidade civilizacional, em suas características "positivas"), apreensível a partir das definições tomadas de Habermas e Demant, esclarece as maneiras como os dois conceitos vão se definindo simultaneamente e mutuamente, ao longo da Idade Moderna, época tanto de criação de um "eu" europeu quanto de sua expansáo e de seu confronto com diversos “outros”, em suas empreitadas coloniais ou em suas disputas territoriais às margens do continente.

Como mostra Demant, a ideia de "Ocidente" vai se constituindo a partir da expansão da ideia de Europa, como conceito civilizacional:

II Habermas está igualmente preocupado em levantar questionamentos sobre as origens ocidentais da modernidade; as experiências históricas que orientam seu diagnóstico da modernidade são aquelas próprias às revoluçóes políticas do século XVIII e suas consequentes manifestaçóes culturais, valorativas e filosóficas. Dessa forma, para Habermas, a modernidade nasceria como um "projeto" no século XVIII, em solo europeu, com a instauração do princípio articulador da subjetividade e - seguindo diagnóstico de Weber - com a separaçáo das esferas de valor: "The Project of modernity formulated in the I8th century by the philosophers of the Enlightenment consisted in their efforts to develop objective science, universal morality and law, and autonomous art, according to their inner logic. At the same time, this project intended to release the cognitive potentials of each of these domains to set them free from their esoteric forms. The Enlightenment philosophers wanted to utilize this accumulation of specialized culture for the enrichment of everyday life, that is to say, for the rational organization of everyday social life" (HABERMAS, I98I, p. 9). 
A ideia era inicialmente menor do que o continente, mas gradativamente se expandiu para incluir todo o continente e incorporar vastas áreas fora dele, criando no processo uma nova ideia: a do "Ocidente"... Essa guinada foi consequência direta dos descobrimentos e da colonização que abriram novas áreas para assentamento europeu no alémmar (DEMANT, 2007, p. 28).

Essa observação de Demant sobre a criação do conceito de Ocidente abre uma porta importante para reflexôes sobre o caráter "ocidental" de uma série de regióes do globo. Essas reflexóes nos são de enorme valia para a desconstrução da identificação entre modernidade e Ocidente. A colônia "é" e "não é” ocidental, simultaneamente. Esse traço "colonial do poder europeu”, que se impóe paulatinamente por vastas áreas e imensas porçóes da população mundial, cria sociedades de "dupla consciência”.

Mignolo, remetendo às análises de Du Bois, fala sobre a "consciência dupla” do homem formado pela colonialidade - dupla, exatamente porque subalterna (MignOLO, 2000, pp. 63-64). Esse princípio é a característica central do imaginário do mundo moderno-colonial, a partir das margens dos impérios europeus. A colônia é, ao mesmo tempo, "mesmidade e diferença" (MignOlO, 2000) ${ }^{\mathrm{I2}}$.

Esses problemas, aqui apenas esboçados, são caminhos a serem percorridos para a problematização daquela identificação inicial entre modernidade e Ocidente, que orienta o discurso sociológico eurocêntrico. A identificação entre Ocidente e modernidade náo fornece os recursos teóricos a partir dos quais se pode realizar uma análise da modernização e da modernidade periféricas - o "fenômeno periférico" se esvai ou é reservado a uma tematizaçáo da "incompletude" e do "atraso".

Como afirma Abdel-Malek com relação às teorias sociais eurocêntricas, o problema crítico fundamental é a reestruturação do aparato conceitual: "O que é real é racional. E este real racional é o do centro hegemônico. É, portanto, a partir de uma exigência de racionalidade - que está no centro de toda a preservaçáo social e de todo o projeto social histórico - que as sociedades não ocidentais são convidadas a se ajustar ao modelo ocidental” (ABDEL-MaLeK, I975, p. 45). "Modelo ocidental" que, no discurso eurocêntrico, pode ser substituído por "modernidade".

Stuart Hall fornece uma importante contribuiçẫo para um esforço de dissociação entre as categorias de modernidade e Ocidente. Esse autor analisa as formas como essas duas "entidades" sáo constituídas como objetos discursivos. O conceito de "Ocidente" seria um significante ligado a uma grande e fluida cadeia de significados (HaLl, I992).

I2 Essa problemática do pertencimento ao Ocidente é um dos temas mais caros à reflexão cultural e sociológica no Brasil - o caráter bifronte das elites coloniais brasileiras (CARDOso, 1975), as obras de Machado de Assis e, novamente, as reflexões de Roberto Schwarz sobre elas a partir da consideração sobre as "ideias fora do lugar" são grandes testemunhos dessa forma de ser colonial e pós-colonial e do sentimento de dualidade próprio à experiência periférica (ver ARANTES, 1992). 
Hall lista quatro áreas principais em que ele circula e opera. Primeiramente, ele funciona como uma categoria analítica que permite mapear o mundo em termos de "Ocidente" e "não Ocidente". Além disso, ele é um critério pelo qual se podem fazer julgamentos sobre o resto do mundo - tanto espacialmente quanto temporalmente. Em terceiro lugar, ele marca uma fronteira em torno da qual uma grande variedade de qualidades positivas e negativas pode ser reunida. Por fim, "Ocidente" é um termo que representa uma forma de vida particular: desenvolvida, industrializada, urbanizada, capitalista, secular e moderna (HaLL, 1992, p. 277).

A partir dessa conceituação de Ocidente e da análise de sua operacionalização, Hall identifica as bases discursivas da identificação, no discurso eurocêntrico, entre as ideias de modernidade e Ocidente. Como aponta Sayyid, essa identificaçáo indica que o termo "Ocidente" refere-se a um projeto - o Ocidente é uma formaçáo ideológica centrada no discurso da modernidade. Segundo esse aparato conceitual, a díade "modernidade-não modernidade" é equivalente à díade "Ocidente-resto" (SAYYID, 2003, pp. IOI-IO2). E a decorrência desse ponto de partida não pode ser outra: modernização passa a ser sinônimo de ocidentalização.

Kaya expressa bem o "resumo da ópera":

In short, modernity emerged as an outcome of a specific civilization, therefore, if the rest wanted to join modern life, they would have first to westernize. In other words, for the rest of societies to modernize, they would first need to "de-easternize" a particular way of life - democratic, civilized and so on - it also had the historical mission of "universalizing" human societies (KaYA, 2004, p. 50).

Tudo leva a crer que esse conceito de modernidade que aqui se critica é unidirecional, não comportando em si a possibilidade da diversidade. Essa visão eurocêntrica da modernidade não comporta a contingência histórica e a agência humana, que condicionam as múltiplas formas de sua realização - tanto em contextos periféricos quanto ocidentais (uma vez que a uniformização do Ocidente é o negativo do discurso eurocêntrico).

Nesse sentido, esforços diversos para uma teoria crítica da modernidade periférica não constituem apenas tentativas de pensar novas categorias a serem contrapostas àquelas próprias ao pensamento eurocêntrico. Antes, pensar criticamente a partir da periferia parece significar examinar as várias formas desse pensar eurocêntrico para descobrir que questôes ele permite colocar e quais outras ficam excluídas, esquecidas.

O que se perde, entấo, ao se eleger a estrutura de referências eurocêntricas como a narrativa mestra da modernidade? Por fim, como se vem tentando pensar para além dessa estrutura e, evidentemente, quais os possíveis ganhos críticos e analíticos dessas tentativas de superação?

Essas consideraçóes - ainda a serem mais extensamente desenvolvidas, por certo - conduzemnos ao exame de uma literatura recente que busca solucionar os dilemas do discurso sociológico

I3 "De-easternize", como abandono da própria identidade, ruptura dos bloqueios à ocidentalizaçáo - sejam essas sociedades "orientais" ou de qualquer outro espaço geográfico periférico. 
eurocêntrico. Sua análise servirá para o aprofundamento das reflexóes teóricas sobre a modernidade, em sociedades periféricas, e para o delineamento de um programa de pesquisa crítico aos discursos eurocêntricos.

\section{INSERINDO A DIVERSIDADE: AVANÇOS E LIMITES DA ABORDAGEM DAS MÚLTIPLAS MODERNIDADES}

Desde meados da década de 1990, diversos cientistas sociais vêm desenvolvendo uma perspectiva teórica que busca romper o viés eurocêntrico nos estudos teóricos e empíricos sobre a modernidade, em suas múltiplas manifestaçóes. Não se trata, evidentemente, da primeira tentativa nesse sentido - e, por certo, nem da mais bem acabada, inclusive pelo fato de os estudos informados por essa perspectiva serem bastante recentes. Contudo, pela posiçáo que vem adquirindo nas ciências sociais e pelo peso do desafio que lança ao discurso eurocêntrico - ao menos no nível da nomenclatura, pela ousadia de tratar a modernidade no plural -, é adequado tratá-la antes de qualquer outro discurso sociológico que se esforce por colocar em questão a identificaçáo entre Ocidente e modernidade, própria à estrutura de referências eurocêntricas hegemônica na história do pensamento social moderno.

A perspectiva das múltiplas modernidades (perspectiva, pois náo seria pertinente tratá-la como teoria) centra-se, sobretudo, em uma análise cultural ou civilizacional. O principal teórico da escola, Shmuel N. Eisenstadt, desenvolve um claro esforço de ampliaçáo do diagnóstico weberiano da modernidade para que possa adequar-se ao estudo dos modos como as outras civilizaçôes (estas, definidas sobretudo em termos religiosos, ao menos por Eisenstadt) realizam de formas diversas a modernidade (EISENSTADT, 2000).

Outra contribuição teórica relevante é a de Charles Taylor, influente filósofo canadense. Esse autor e Benjamin Lee apontam que a maioria das teorias da modernização é "acultural". Esse tipo de teoria postularia que qualquer sociedade pode passar por um processo de modernizaçáo que as levaria a um resultado final bastante semelhante. As teorias aculturais tendem a descrever essa transição em termos da perda das crenças e solidariedades tradicionais, em decorrência de mudanças institucionais, demográficas ou da crescente operacionalização da razão científica.

Essa "tese da convergência" é o principal alvo de crítica da perspectiva das múltiplas modernidades (TAYLOR \& LEE, 2008). Segundo aquela postura eurocêntrica, a modernidade, para sociedades que náo fazem parte de seu centro irradiador, apareceria como um ponto de chegada - nesse processo, como não poderia deixar de ser, "this means, of course, that we expect they will end up looking like us" (TAYLOR \& LEE, 2008).

Como se pode apreender do que foi mencionado anteriormente, essa perspectiva descrita por Taylor não se resume à teoria da modernizaçáo, tão em voga até a década de 60 . Como aponta Smith, esse modelo eurocêntrico, mais ou menos etapista, continua a exercer efeitos poderosos sobre as ciências sociais, por meio de um background residual de hipóteses e modelos de pensamento, mesmo quando o acadêmico não é um modernization scholar (SMITH, 2008, p. I). 
Eisenstadt tenta desenvolver a ideia de que o processo de modernização náo equivale ao de ocidentalizaçáo. Ele busca descrever as várias formas pelas quais os processos de diferenciação estrutural desenvolveram-se nas diversas culturas do globo, gerando múltiplos padrôes institucionais e ideológicos. Esses padrôes, contudo, não seriam meras continuaçôes das tradiçốes de cada uma dessas sociedades: cada um deles é distintivamente moderno, apesar de fortemente influenciados por suas premissas, tradiçóes e experiências culturais.

Eisenstadt resume da seguinte maneira o projeto (em construção) das múltiplas modernidades:

The idea of multiple modernities presumes that the best way to understand the contemporary world - indeed to explain the history of modernity - is to see it as a story of continual constitution and reconstitution of a multiplicity of cultural programs. These ongoing reconstructions of multiple institutional and ideological patterns are carried forward by specific social actors in close connection with social, political and intellectual activists, and also by social movements pursuing different programs of modernity, holding very different views on what makes societies modern. Through the engagement of these actors with broader sectors of their respective societies, unique expressions of modernity are realized (EISENSTADT, 2000, p. 2).

O raciocínio de Eisenstadt implica que, apesar de a "modernidade ocidental" gozar de precedência histórica e de continuar sendo o ponto de referência para as outras sociedades (ou civilizaçôes), ela não constituiria qualquer tipo de modelo "autêntico" de modernidade (EIsenstadt, 2000, p. 3). Além disso, a própria cristalização da modernidade europeia não teria sido um processo unidirecional e pacífico, mas teria sido derivada de uma série de lutas, internas e externas, assentadas nas contradiçôes e tensôes próprias do desenvolvimento do capitalismo, da constituição dos estados e das disputas pela democratizaçáo.

Com a expansão europeia, no início da Época Moderna, sobretudo nas Américas, teria havido a primeira transformaçáo das premissas da ordem cultural e política daquela modernidade em gestação (Eisenstadt, 2000, p. I3). Essa consideração de Eisenstadt o leva a postular que "a modernidade" já nasceu múltipla, mas a partir de variaçóes do modelo europeu - algo que parece se manter em todo o raciocínio de Eisenstadt: “(...) practically from the beginning of modernity's expansion multiple modernities developed, all within what may be defined as the Western civilizational framework" (EISENSTADT, 2000, p. I3).

O raciocínio de Eisenstadt, apesar de avançar com relaçăo à conceituação de modernidade, ainda sofre de certo grau de "difusionismo". Isso ocorre apesar da defesa de Eisenstad de que a civilizaçấo europeia e seus produtos e manifestaçôes não são imediatamente transplantados em outros lugares do globo. Para o autor, a modernidade "se moveu" ao redor do globo, por meio do colonialismo e do imperialismo, dada a superioridade militar, econômica e tecnológica europeia. 
Como aponta Schmidt, os proponentes da abordagem das múltiplas modernidades (e isso é verdadeiro, sobretudo com relação às contribuiçôes de Eisenstadt) concordam com os teóricos da modernização de que o "projeto da modernidade", "a partir do momento em que ele firmemente deitou raízes no Ocidente, começou logo a ter uma relevância global e a espalhar-se para o que às vezes é depreciativamente chamado de 'o resto"' (SСнмidT, 2007, p. I49).

Esse parece ser um ponto de tensão no interior do projeto, uma vez que outros autores, como Göle (2000; 2002) e Kaya (2004), por exemplo, insistem muito menos na questáo da expansão e da seguinte diferenciação de uma modernidade "original" - apesar de não "autêntica", como a descreve Eisenstadt.

De qualquer forma, um ponto importante em que insiste Eisenstadt e outros autores que compartilham dessa perspectiva é a ideia de que a realizaçáo da modernidade nas diversas sociedades e civilizaçóes deriva-se de uma permanente seleção, reinterpretaçáo e reformulaçáo das ideias importadas.

O processo de "modernizaçáo seletiva" ${ }^{14}$ permite estudar como as múltiplas manifestaçóes daquele projeto original de modernidade se realizariam em sociedades de modernizaçáo posterior. Entretanto, é preciso apontar que, até o momento, os principais trabalhos que se inserem nessa perspectiva não se centraram nas disputas internas, mas nas formas como as tradiçóes culturais impactaram na constituição de cada uma das modernidades. $\mathrm{O}$ argumento de Eickelman é exemplar desse ponto de vista:

"Traditions" are clusters of cultural concepts, shared understandings, and practices that make political and social life possible. Such pervasive cultural understandings play a crucial element in constituting what we now recognize as "multiple modernities". They coexist with and shape the experience of modernity. In this sense, ethnicity, caste, and clientelism can be as distinctively modern as the idea of individual choice (EICKELMAN, 2000, p. I22).

Taylor e Lee, no mesmo sentido, afirmam que o principal motivo pelo qual se pode falar em múltiplas modernidades é o fato de que o ponto de partida cultural deixa suas impressóes no resultado final. Uma transição de sucesso para a modernidade exigiria que um povo encontrasse recursos em sua cultura tradicional, que, modificados, permitiriam que eles dispusessem das novas práticas. A esse processo os autores dáo o nome de "adaptação criativa" (TAYLOR \& LEE, 2008).

Dessa maneira, a modernidade, nessa perspectiva, cristaliza-se em torno das grandes civilizaçôes - como a europeia, a islâmica, a hindu, etc. -, sendo que cada uma delas deixaria suas impressôes nas instituiçốes da sociedade, "dando-lhes sua forma e 'cor', por assim dizer" (SCHMIDT, 2007, p. I50), ou seja, constituindo modernidades particulares a partir da absorção

I4 Tomo emprestado aqui o título do livro de Jessé Souza (2000), que, apesar de náo mobilizar a perspectiva das múltiplas modernidades, fornece um ótimo exemplo de um estudo que tenta entender a realizaçáo específica (no caso, no Brasil) da modernidade, a partir de um processo "seletivo", resultado das disputas entre grupos internos. 
de valores e instituiçôes que se conformassem de formas específicas com os dados culturais formadores de cada uma dessas civilizaçôes.

É de se observar, inicialmente, que a perspectiva das múltiplas modernidades fornece uma séria resposta ao tratamento das sociedades não ocidentais como formas insuficientes de realizaçáo da modernidade. Como argumenta Kaya, essa perspectiva oferece ferramentas para o tratamento da modernidade como um horizonte aberto, em que existe espaço para múltiplas interpretaçóes. A modernidade náo é um projeto definido e civilizacional, mas um campo de tensôes (KAYA, 2004, p. 38). Ao entendê-la dessa maneira - ao invés de vê-la como uma linha de chegada, um desiderato de uniformização -, esses autores propóem essa significativa ruptura epistemológica, que possibilita a compreensáo da modernidade como um programa que incluiria a multiplicidade, a contingência:

Thus, it may be said that since, contrary to postmodernism, modernity is an open, rather than a closed, way of life, it is not necessary to work outside modernity... Because modernity is in the streets, rather than being a programme, plural and different life perspectives compete for the good life. What could be emphasized is that modernity is an endless trial, because no centre provides the 'content' for social life (KAYA, 2004, pp. 47-48, destaque colocado).

Uma modernidade "que está nas ruas" é uma maneira astuta de definir um projeto teórico que busque dar conta das formas concretas de realização da modernidade e tente afastar-se de discursos eurocêntricos ou da ideia da modernidade como um "projeto" fundamentalmente normativo.

Apesar dos avanços da perspectiva das múltiplas modernidades que se tentou brevemente expor até o momento, é preciso apontar que o projeto ainda demonstra uma série de inconsistências, além de basear-se em pontos de partida teóricos problemáticos, que limitam a extensão possível de seus desdobramentos. As críticas que a seguir serão arroladas são os motivos principais de nossa consideração da necessidade de se avaliarem outras tradiçóes teóricas antieurocêntricas, que permitam uma consideração da modernidade periférica para além da diversidade oferecida por essa perspectiva.

Inicialmente, é necessário apontar que os autores que vêm trabalhando no interior dessa perspectiva - sobretudo aqueles que seguem mais de perto as abordagens teóricas de Eisenstadt - centram-se demasiadamente na realização civilizacional ou religiosa da modernidade. Esse ponto de partida teórico reduz drasticamente as potencialidades do próprio projeto, além de resvalar em um sério risco de essencialização - não mais uma essencialização dicotômica, própria ao discurso eurocêntrico, mas uma essencialização de cada uma dessas civilizaçóes. Essas vias abertas no interior da perspectiva das múltiplas modernidades correm o risco de desembocar em armadilhas muito semelhantes às do discurso eurocêntrico ${ }^{\text {I5 }}$.

I5 Spohn (Spohn, 2006, p. 5) aponta que, mesmo no interior desse paradigma civilizacional, essa perspectiva relega a um segundo plano uma análise da interação entre as diferentes civilizaçôes - crítica que é complementar à anterior, que aponta os riscos da essencialização. 
Além disso, a escolha dos padróes culturais tradicionais como ponto de partida para a análise da absorçấo do moderno incorre em um risco de não se levantarem questôes relevantes acerca de diferenças sociais no interior de civilizaçóes ou de estados. Dito de outra maneira, os trabalhos informados por essa perspectiva não se atêm à estratificação social e às disputas que envolvem a "escolha" das formas de participação na modernidade (apesar de se referirem a clivagens internas, mas sem que isso seja incorporado de forma efetiva em seus aparatos teóricos ou em suas análises de sociedades específicas ${ }^{16}$.

Não se trata, aqui, de uma sugestáo para que se substitua uma perspectiva civilizacional ou nacional por uma de classe, mas da necessidade de se incorporar ambas ${ }^{17}$. Uma abordagem teórica que pretenda explicar os processos de modernização em sociedades periféricas deve ser capaz de explicar a dialética entre o universal e o particular ou entre o externo e o interno, envolvida nesse processo.

Não me parece, por exemplo, que uma reflexão sobre a "modernidade italiana" informada por essa perspectiva teria relação com o problema crucial, classicamente colocado por Gramsci, acerca da "Questáo Meridional" (conforme Gramsci, 1987), ou seja, o problema das relaçóes entre o norte e o sul da Itália, em sua passagem para a modernidade capitalista, e as consequentes disparidades sociais entre as duas regióes.

Além disso, o fato de centrar-se quase exclusivamente em variáveis culturais afasta essa perspectiva de uma consideração mais atenta à lógica do capitalismo mundializado e às diferentes inserçóes nele de estados e regiốes. Essa, provavelmente, é a grande diferença entre essa perspectiva e os estudos sobre a dependência - que podem ser entendidos como uma extensão e uma atualizaçáo das teorias do imperialismo, mas com a atenção voltada para as dinâmicas internas aos países periféricos.

Ao náo dar centralidade ao capitalismo, esses autores não conseguem realizar uma adequada análise das disparidades de poder global que marcam o sistema internacional - seja desde o século XVI, com a expansão marítima europeia, seja desde o século XVIII, com a Revolução Industrial (para essa discussão, consultar Demant, 2007, e Blaut, 2000).

I6 Knöbl aponta que a América Latina foi uma região praticamente esquecida pelos estudos informados pela perspectiva das múltiplas modernidades. Ele observa que “(...) uma das razôes desse esquecimento está com certeza ligada ao fato de que os debates sobre a posiçáo da América Latina se deram no âmbito da teoria dos sistemas mundiais ou da teoria da dependência. Visto que ambas tendem a diminuir a importância de momentos culturais táo relevantes para a maioria dos autores que defendem o paradigma das 'múltiplas modernidades', é perfeitamente compreensível que poucos desses autores ousem penetrar no campo dos estudos latino-americanos" (KNöBL, 2006, p. 505). Essa observação de Knöbl é complementar ao que se afirmou até o momento e mostra a pertinência de abordagens teóricas que considerem tanto a economia política quanto as dinâmicas culturais envolvidas nos processos de modernização. I7 Essa advertência serve para que essa observação não se assemelhe ao tipo de crítica apresentada por Francisco Weffort às perspectivas da dependência. Weffort aponta uma ambiguidade entre naçáo e classe, no interior dos estudos de dependência, além de afirmar que uma teoria de classes não precisaria de uma premissa nacional para explicar o desenvolvimento capitalista (WefForT, 197I). A resposta de Cardoso, que considero bastante consistente, aponta para a inexistência de uma cisão metafísica entre interno e externo: a dinâmica interna dos países dependentes é um aspecto mais particular da dinâmica externa do mundo capitalista (CARDOSO, 1979). 
A ideia de uma "adaptação criativa" ou de um caráter seletivo da absorção da modernidade, se não se atém a essas disparidades materiais (que se convertem e enredam em vantagens simbólicas), parece sugerir que existe um mercado de práticas e padróes de sociabilidade modernos à disposiçẫo de cada uma das sociedades ou civilizaçôes, que devem prová-los para ver qual combina melhor com seu porte físico "tradicional"18.

A partir do que se tentou expor até aqui, parece bastante convincente a hipótese de que a perspectiva das múltiplas modernidades pode servir, no máximo, como um primeiro momento lógico de superação do discurso eurocêntrico. Ao tratar as modernidades no plural, esses autores implodem inicialmente as dicotomias do pensamento eurocêntrico, uma vez que apontam a não unicidade histórica da realização da modernidade segundo um molde específico.

Dessa forma, essa perspectiva propóe o desafio de lançar um olhar para a modernidade como algo diferente de um ponto de chegada ou de um padrão de averiguação da completude de experiências históricas. Contudo, essa perspectiva deve ser complementada por outras abordagens que superem suas fragilidades, aproximando-nos de um programa teórico aberto e eclético que considere diferentes tentativas teóricas de superaçấo dos discursos sociológicos eurocêntricos e que nos aproxime de uma conceituaçáo de modernidade que propicie uma justa análise da modernidade em sociedades periféricas.

A superaçáo de suas fragilidades significa, sobretudo, que se deve pensar em maneiras de teorizar a história da modernidade e de sua constituição como uma história global ou como um conjunto de histórias entrelaçadas, para além do quadro de diversidade apresentado por essa perspectiva.

O momento da diversidade deve dar lugar ao momento da dialética entre a modernidade como processo universal e suas múltiplas realizaçôes particulares. Os caminhos que seguimos até o momento e as críticas apresentadas tanto às diversas formas de discurso eurocêntrico quanto à perspectiva das múltiplas modernidades apontam para a consideração da modernidade como um fenômeno global, como uma totalidade de totalidades, estas realizaçôes específicas daquela modernidade global.

É relevante apontar, mais uma vez, que essa reorientação teórica não é um projeto original, uma espécie de mata virgem antieurocêntrica ainda a ser desbravada. Creio, pelo contrário, que uma série de formulaçôes teóricas advindas de tradiçōes diversas (e, sobretudo, da tradiçấo marxista e dos estudos pós-coloniais), críticas ao paradigma eurocêntrico da modernidade, permitem que se aponte para uma teoria crítica da modernidade global - modernidade vista como

I8 Como afirma Dube: "In speaking of modernities are we merely saying that Indian modernity is different from German modernity, which is then different from, say, Mexican or Venezuelan modernity? If this is the case, what modalities of power are occluded here, not only in relation to authoritative grids of empire and globalization, but also within non-Western formations of state and nation? Equally, by invoking a bloated and singular modernity centered on the West in order to interrogate the homogenizing impulses of projects of power, do we perhaps succumb to reified representations of an imaginary but tangible Europe that overlook the labor of difference within the work of domination?" (DuBE, 2002, p. 200). 
uma totalidade, cuja autonomia se encontra nas inter-relaçöes de suas unidades; essas são, também, totalidades, ao mesmo tempo em que são parcialidades da totalidade maior ${ }^{19}$.

Essa consideração da unidade dialética entre a modernidade e suas múltiplas manifestaçóes abre caminhos para que estas sejam encaradas em sua dignidade histórica; ao mesmo tempo, ela convida a uma consideraçáo da modernidade que possa incorporar sua própria crítica, a partir da periferia - ou seja, ela fornece o solo para uma teoria crítica da modernidade periférica que seja, ao mesmo tempo, uma teoria critica da modernidade. Um programa crítico desse tipo tentaria tirar as maiores consequências de uma consideração como a de Marx, de que a "colônia revela as entranhas da metrópole”. Em uma proposta de pesquisa próxima à que aqui se apresenta, Boaventura de Sousa Santos (2004, p. I9), em diálogo com os estudos pós-coloniais, propôe um posicionamento "(...) nas margens ou periferias mais extremas da modernidade ocidental para daí lançar um novo olhar crítico sobre ela”.

Portanto, não se trata exclusivamente de uma questão de acuidade científica, mas, igualmente, de uma tentativa de pensar criticamente a condiçáo periférica e, a partir dela, a modernidade. Seguindo as instigantes sugestóes de Paulo Arantes, parece-me que o "atraso" (ou a condiçáo periférica) pode conduzir a novas formas de pensar e ser revelador de processos sociais que estáo além dele mesmo (Arantes, 1992; 1996; consultar também Mignolo, 2003; Santos, 2004).

A periferia, dessa maneira, pode servir como lugar de onde parte a crítica de toda a modernidade, não mais como o outro dessa modernidade, mas como parte dela mesma ${ }^{20}$. Essa espécie de reorientação da perspectiva da história mundial a partir da qual é narrada a história da modernidade, em suas várias manifestaçóes, não deve servir, entretanto, a um projeto de justificaçáo do pretenso atraso e de todas as formas de mazelas que acometem a periferia, mas, ao contrário, como forma de entender esse projeto como parte do fenômeno da modernidade.

I9 Essa formulação é inspirada, sobretudo, em duas fontes: a descrição de Paulo Freire sobre a constituição do sistema da Pedagogia do Oprimido (Freire, 2007 [I968], p. I35) e a definição do conceito de totalidade em Hegel, fornecido por Martin Jay. Cito este trecho, bastante elucidativo: "(...) by employing the term 'totality' to refer to all coherent entities within the cosmic whole, Hegel encouraged the vision that lesser or partial totalities existed on all levels of the meta-totality. This acceptance of what we have called 'latitudinal totalities' meant that any part in a larger whole might itself be considered an organized whole from the perspective of its internal dynamics. Thus reality for Hegel was populated by multitudes of hierarchically linked or horizontally juxtaposed totalities, which defied comprehension through reduction to their component parts" (JaY, I984, p. 59).

20 Crítica essa que não exclui outras formas de discursos críticos a essa mesma modernidade, mas que se articula a eles tendo em vista uma forma específica de subalternização, com base em um ponto de vista geo-historicamente marcado (consultar Mignolo, 2002). Abdel-Malek observou muito bem que "a hegemonia das minorias possuidoras revelada por Marx e Engels e o antropocentrismo desmantelado por Freud seguem de mãos dadas com o eurocentrismo nas Ciências Humanas e Sociais, principalmente naquelas que têm relação direta com os povos não europeus" (citado em Wallerstein, 2007, p. 68). A crítica antieurocêntrica ou descolonial é, portanto, um "momento" específico de uma teoria crítica da modernidade. Enfatizo aqui a ideia de que se trata de um "momento", uma vez que essa perspectiva, como vem sendo avançada nos principais trabalhos recentes, não exclui ou abre máo de outras teorias críticas da modernidade - como, por exemplo, os trabalhos pós-estruturalistas ou frankfurtianos -, mas os complementa, a partir da crítica à colonialidade da modernidade. 
$\mathrm{Na}$ forma de uma mal acabada conclusão, gostaria de apontar alguns caminhos que podem ser trilhados em busca de respostas a esses problemas teóricos apontados. Acredito que esse movimento de constituição de uma teoria crítica da modernidade periférica deve passar por uma articulação de perspectivas teóricas diversas, as quais se propóem a falar a partir da periferia. Como sugiro anteriormente, considero, sobretudo, a possibilidade de um diálogo entre as teorias pós-coloniais e as teorias elaboradas no interior da tradiçáo marxista que tratam do caráter assimétrico do capitalismo global - em particular os "estudos da dependência".

Tal diálogo deve servir para o encaminhamento de uma consideração sobre as formas de dominação materiais e simbólicas mundiais, ou seja, sobre as dinâmicas entrelaçadas de um capitalismo e uma modernidade globais e de suas formas de realização particulares ${ }^{21}$.

Esse movimento de diálogo teórico deve ocorrer de forma simultânea a uma reflexão sobre o pensamento social em naçóes periféricas - em grande medida, desenvolvido para dar conta da compreensão dos destinos da modernidade nessas sociedades. Sociedades essas que não foram "contempladas pelos clássicos", mas que - por isso ou apesar disso - esforçaram-se em lançar um olhar sobre si próprias e sobre o mundo, a partir de suas experiências de modernidade.

\section{FONTES CONSULTADAS}

Abdel-Malek, Anouar. Dialética social: fundamentos para uma teoria social mundializante. Rio de Janeiro: Paz e Terra, 1975.

Ahmad, Aijaz. Linhagens do presente. São Paulo: Editora Boitempo, 2002.

Amadeo, Javier; Rojas, Gonzalo. Marxismo, pós-colonialidade e teoria dos sistemas-mundo. In: Encontro Anual da Anpocs, 3i. 2007. Disponível em: <http://20I.48.I49.89/anpocs/ arquivos/15_IO_2007_II_3_38.pdf>. Acesso em: 02 de agosto de 2008.

Anderson, Perry. Linhagens do Estado Absolutista. São Paulo: Editora Brasiliense, 1985.

Arantes, Paulo E. Sentimento da dialética na experiência intelectual brasileira. São Paulo: Paz e Terra, I992.

Ressentimento da dialética. Sáo Paulo: Paz e Terra, 1996.

Aricó, José. Marx e a América Latina. Rio de Janeiro: Paz e Terra, 1982.

Bartolovich, Crystal; Lazarus, N. (Eds.) Marxism, modernity, and postcolonial studies. New York: Cambridge University Press, 2002.

2I Alguns outros trabalhos já sugeriram a necessidade da aproximação entre as teorias pós-coloniais e uma análise do capitalismo global, sobretudo a partir da teoria dos Sistemas Mundo (consultar Mignolo, 2003; Amadeo \& Rojas, 2007; BARTOLOVICH \& LAZARUS, 2002). Trata-se, dessa forma, de um trabalho em andamento, que ainda está por gerar resultados teóricos bem desenvolvidos e análises empíricas por eles embasadas. 
Bernal, Martin. Black Athena: Afroasiatic roots of classical civilization. v. I. The Fabrication of Ancient Greece, I785-I985. Piscataway, NJ: Rutgers University Press, 1987.

Blaut, James. Eight eurocentric historians. New York: Guilford Press, 2000.

Brandão, Gildo M. Ideias e intelectuais: modos de usar. Lua Nova, São Paulo, n. 54, pp. 25-42, $200 I$.

Cardoso, Fernando H. Autoritarismo e democratização. Rio de Janeiro: Paz e Terra, I975.

. “Teoria da Dependência’ ou análises concretas de situaçôes de dependência?”. In:

Cardoso, Fernando H. O modelo político brasileiro. São Paulo: Difel/Difusão Editorial S. A., I979.

Chakrabarty, Dipesh. Provincializing Europe. Princeton: Princeton University Press, 2000.

Coronil, Fernando. "Naturaleza del poscolonialismo: del eurocentrismo al globocentrismo". In: LANDER, Edgardo (Org.) La colonialidad del saber: Eurocentrismo y Ciencias Sociales - Perspectivas latino-americanas. Buenos Aires: Clacso, 2000.

. "Latin American postcolonial studies and global decolonization". In: LazArus, Neil. The Cambridge Companion to Postcolonial Literary Studies. New York: Cambridge University Press, 2004.

Costa, Sérgio. Desprovincializando a Sociologia: a contribuição pós-colonial. Revista Brasileira de Ciências Sociais, v. 6o, n. 2I, pp. II7-I34, 2006.

Demant, Peter. Choque dos universalismos: estudos sobre a interação Ocidente-Islá. 2007. Tese (Livre-Docência) - Departamento de História, Faculdade de Filosofia Letras e Ciências Humanas, Universidade de São Paulo. São Paulo, 2007.

DirLIK, Arif. "The postcolonial aura: third world criticism in the age of global capitalism”. In: Mongia, Padmini. Contemporary postcolonial theory: a reader. New York: Oxford University Press, 2003.

Dube, Saurabh. Colonialism, modernity, colonial modernities. Nepantla, v. 3, n. 2, pp. 197-219, 2002.

Dussel, Enrique. "Europa, modernidad y eurocentrismo". In: Lander, Edgardo (Org.) La colonialidad del saber: Eurocentrismo y Ciencias Sociales - Perspectivas latino-americanas. Buenos Aires: Clacso, 2000.

Eickelman, Dale. Islam and the languages of modernity. Daedalus, pp. II9-I35, 2000.

Eisenstadt, S. N. Multiple modernities. Daedalus, pp. I-29, 2000.

Foucault, Michel. As palavras e as coisas. São Paulo: Martins Fontes, 2007 [1966]. 
. A arqueologia do saber. Rio de Janeiro: Forense Universitária, 2007 [1969].

- Vigiar e punir. São Paulo: Editora Vozes, 2006 [1975].

Freire, Paulo. Pedagogia do oprimido. Rio de Janeiro: Paz e Terra, 2007 [I968].

GöLE, Nilufer. Snapshots of Islamic modernities. Daedalus, pp. 9I-II7, 2000.

. Islam in public: new visibilities and new imaginaries. Public Culture, v. I, n. I4, pp. I73-190, 2002.

Gramsci, Antonio. A questão meridional. Rio de Janeiro: Paz e Terra, 1987.

Habermas, Jurgen. Modernity versus Post-Modernity. New German Critique, v. 22, pp. 3-I4, I98I. . O discurso filosófico da modernidade: doze liçôes. São Paulo: Martins Fontes, 2002.

Hall, Stuart. "The West and the Rest: discourse and power". In: Hall, S.; Gieben, B. (Eds.) Formations of modernity. Cambridge: Polity Press/ Open University, I992.

Jani, Pranav. "Karl Marx, eurocentrism and the I857 revolt in British India". In: Bartolovich, Crystal; Lazarus, Neil (Eds.) Marxism, modernity, and postcolonial studies. New York: Cambridge University Press, 2002.

JAY, Martin. Marxism and totality: the adventures of a concept from Lukács to Habermas. Cambridge: Polity Press, 1984.

KaYA, Ibrahim. Modernity, openness, interpretation: a perspective on multiple modernities. Social Science Information, v. I, n. 43, pp. 35-57, 2004.

KNöBL, Wolfgang. Max Weber, as múltiplas modernidades e a reorientação da teoria sociológica. Dados, v. 3, n. 49, pp. 483-509, 2006.

LANDer, Edgardo. “Ciências Sociales: saberes coloniales y eurocéntricos”. In: Lander, Edgardo (Org.). La colonialidad del saber: Eurocentrismo Y Ciencias Sociales - Perspectivas Latinoamericanas. Buenos Aires: Clacso, 2000.

Löwy, Michael. As aventuras de Karl Marx contra o Barão de Munchhausen. 9. ed. São Paulo: Cortez, 2007.

Mignolo, Walter D. "La colonialidad a lo largo y a lo ancho: el hemisferio occidental en el horizente colonial de la modernidad”. In: LANDER, Edgardo (Org.) La colonialidad del saber: Eurocentrismo y Ciencias Sociales - Perspectivas latino-americanas. Buenos Aires: Clacso, 2000.

. The geopolitics of knowledge and the colonial difference. The South Atlantic Quarterly, v. IOI, n. I, pp. 56-96, 2002. 
. Histórias locais/projetos globais: colonialidade, saberes subalternos e pensamento liminar. Belo Horizonte: Editora UFMG, 2003.

Moore-Gilbert, Bart. Postcolonial Theory: contexts, practices, politics. London: New York, 1997.

Nimtz, August. "The Eurocentric Marx and Engels and other related myths". In: Bartolovich, Crystal; Lazarus, Neil (Eds.) Marxism, modernity, and postcolonial studies. New York: Cambridge University Press, 2002.

Pierucci, Antônio F. O desencantamento do mundo: todos os passos do conceito em Max Weber. São Paulo: USP, Curso de Pós-Graduação em Sociologia; Ed. 34, 2003.

Quijano, Aníbal. "Colonialidad del poder, eurocentrismo y América Latina". In: Lander, Edgardo (Org.) La colonialidad del saber: Eurocentrismo y Ciencias Sociales - Perspectivas latino-americanas. Buenos Aires: Clacso, 2000.

SAID, Edward W. Orientalism. New York: Vintage Books, 2003 [1978]. . Cultura e imperialismo. São Paulo: Companhia das Letras, I995 [1993].

Santos, Boaventura de Sousa. Do Pós-Colonial ao Pós-Moderno e para além de um e de outro. Disponível em: <http://www.ces.uc.pt/misc/Do_pos-moderno_ao_pos-colonial.pdf>. Acesso em: 3I de julho de 2004.

SAYYID, Bobby S. A fundamental fear: eurocentrismo and the emergence of Islamism. London, New York: Zed Books, 2003.

Schluchter, Wolfgang. Paradoxes of modernity: culture and conduct in the Theory of Max Weber. Stanford: Stanford Unversity Press, 1996.

Schmidt, Volker H. Múltiplas modernidades ou variedades da modernidade. Revista de Sociologia Política, n. 28, pp. I47-I60, 2007.

Schwarz, Roberto. "Ideias fora do lugar." In: Schwarz, Roberto. Ao vencedor as batatas: forma literária e processo social nos inícios do romance brasileiro. São Paulo: Livraria Duas Cidades; Ed. 34, 2000 [1977].

Sнонат, Ella; Stam, Robert. Crítica da imagem eurocêntrica. São Paulo: Cosac Naify, 2006.

Sмiтн, Christian. On multiple modernities: shifting the modernity paragidm. Disponível em: <http://www.nd.edu/-csmith22/documents/MultipleModernities.pdf>. Acesso em: 3I de julho de 2008.

SouzA, Jessé. A modernizaçâo seletiva: uma reinterpretaçáo do dilema brasileiro. Brasília: Editora $\mathrm{UnB}, 2000$. 
Sponn, Wilfred. "Multiple, entangled, fragmented and other modernities. Reflections on comparative-sociological research on Europe, North and Latin America”. In: Costa, Sérgio et al. (Eds.) The plurality of modernity: Decentering Sociology. Munchen: Hampp, 2006.

Tavolaro, Sergio B. F. Existe uma modernidade brasileira? Reflexôes em torno de um dilema sociológico brasileiro. Revista Brasileira de Ciências Sociais, v. 59, n. 20, pp. 5-22, 2006.

TAYlor, Charles; LeE, Benjamin. Multiple modernities project: modernity and difference. Disponível em: <http://www.sas.upenn.edu/transcult/promad.html>. Acesso em: 02 de agosto de 2008 .

Turner, Bryan S. Capitalismo y clases en el Medio Oriente. México, DF: Fondo de Cultura Econômica, 1989 .

. Orientalism, postmodernism and globalism. London: Routledge, I994.

Wallerstein, Immanuel. O Universalismo Europeu. São Paulo: Boitempo Editorial, 2007.

Weffort, Francisco C. Notas sobre a "Teoria da Dependência": Teoria de Classe ou Ideologia Nacional? Estudos Cebrap, n. I, pp. 2-24, I97I.

Werneck Vianna, Luiz. A Revolução Passiva: iberismo e americanismo no Brasil. Rio de Janeiro: Revan, I997. 